\title{
European Central Bank Efforts for Covid-19 Referring to the Previous Crises
}

\section{Fatbardha Kadiu}

Prof. Assoc., PhD, University of New York Tirana

Department of Finance and Economics, Albania

\begin{abstract}
Considering the reaction of Italian Government directed to European Central Bank, I intend to search if the ECB have the same reactions for the Covid-19 crises as the bank had for the previous crises of 2008-2010 financial crises and the Eurozone debt crises. The paper covers the factors of the crises by analyzing the causes and the results of each crises very briefly and mainly making a comparison for the respecting responses that the bank had for each of them. It is noticed that the efforts or the responses are not the same, and in fact as the profiles of the crises are different it is hard to find same responses but the conclusion I could find is that responses are equivalent to each other for the three analyzed crises. The only difference is the time applied of its policies (and the dimension of time in quasi -fiscal policy applied is crucial) and the details for the APP (Asset Purchasing Program) which are not already published and the rate on interests. Of course by this conclusions I find it somehow very objective the Italian government reactions to the European Central Bank and the European Union identified as Union with the core value of "solidarity". Of course the research need further studies to conclude if the responses of ECB itself are coherent with the macroeconomic situation of the whole world and if there is any connection between the policies taken by ECB.
\end{abstract}

Keywords: ECB, COVID-19 crises, APP, Bank policies, Quasi-Fiscal Policy

\section{Introduction}

Considering the breakdown of the covid-19, where many countries dealt with a real challenge not only psychologically but most of all economically. Business closed and people remaining without a job was kind of shock for the society. Of course different countries had different responses during pandemic time, some nations had to deal in a more savage way that the others. One of them of course was Italy, with e record number (in percentage) of people infected and dead during March-April 2020.

Mrs. Lagarde with her first press conference broke the hope on millions of Italians that were dealing with the psychological war with the idea of "the Governing Council decided to keep the key ECB interest rates unchanged" (Christine Lagarde, 12 March 2020). Of course maybe just from the banking system perspective it did not meant any mistake, but politically and considering the solidarization values that accompanied the EU from its beginning it was kind of "breaking the rule". Any nation within EU knows that EU came out because of two main 
concepts: by solidarization of all nations' surpluses and deficits and because of the Marshall plan.

Of course many researches, policy makers, professors at time during pandemic were kind emotionally involved. From this point of view I made this modest research to see if the ECB had the same approach as the previous crises as to this crises too?

I will be describing the main factors of the 2008-2010 crises, Eurozone debt crises and Covid19 crises. On the other hand I will describe and list of the main responses that the European Central Bank had for each of them, and at the end to find out if the CBE did not had the same approach for all this last crises.

\section{Literature Review}

\section{8-2009 Financial crises, causes and results}

As we all know already in 2006, housing prices started to fall for the first time in decades. At first, realtors applauded. They thought the overheated real estate market would return to a more sustainable level. They didn't realize there were too many homeowners with questionable credit. In addition, banks had approved loans for $100 \%$ or more of the home's value.

The 2008-2009 financial crisis was the worst economic disaster since the Great Depression of 1929. It occurred despite the efforts of the Federal Reserve and U.S. Department of the Treasury. The crisis led to the Great Recession, where housing prices dropped more than the price plunge during the Great Depression. Two years after the recession ended, unemployment was still above $9 \%$. That does not count those discouraged workers who had given up looking for a job. (Albulescu, C., \& Goyeau, D., 2013).

Deregulation of financial derivatives was a key underlying cause of the financial crisis.

The financial crisis was primarily caused by deregulation in the financial industry. That permitted banks to engage in hedge fund trading with derivatives. Banks ${ }^{1}$ then demanded more mortgages to support the profitable sale of these derivatives. They created interest-only loans that became affordable to subprime borrowers. (Trichet, 2010).

One other area involved in this crises were securitization. First, hedge funds and others sold mortgage-backed securities, collateralized debt obligations, and other derivatives. A mortgage-backed security ${ }^{2}$ is a financial product whose price is based on the value of the mortgages that are used for collateral. Once you get a mortgage from a bank, it sells it to a hedge fund on the secondary market. The hedge fund then bundles your mortgage with a lot of other similar mortgages. They used computer models to figure out what the bundle is worth based on several factors. These included the monthly payments, the total amount owed, the likelihood you will repay, and future home prices. The hedge fund then sells the mortgagebacked security to investors. Since the bank sold your mortgage, it can make new loans with

\footnotetext{
${ }^{1}$ Note: Only big banks had the resources to become sophisticated at the use of these complicated derivatives. The banks with the most complicated financial products made the most money. That enabled them to buy out smaller, safer banks. By 2008, many of these major banks became too big to fail.

2 Note: Banks offered subprime mortgages because they made so much money from the derivatives, rather than the loans themselves.
} 
the money it received. It may still collect your payments, but it sends them along to the hedge fund, who sends it to their investors. Of course, everyone takes a cut along the way, which is one reason they were so popular. It was basically risk-free for the bank and the hedge fund.

The investors took all the risk of default, but they didn't worry about the risk because they had insurance, called credit default swaps. These were sold by solid insurance companies like the American International Group. Thanks to this insurance, investors snapped up the derivatives. In time, everyone owned them, including pension funds, large banks, hedge funds, and even individual investors. Some of the biggest owners were Bear Stearns, Citibank, and Lehman Brothers.

A derivative backed by the combination of both real estate and insurance was very profitable. As the demand for these derivatives grew, so did the banks' demand for more and more mortgages to back the securities. To meet this demand, banks and mortgage brokers offered home loans to just about anyone. (Albulescu, C., \& Goyeau, D., 2013).

In 2005, homebuilders finally caught up with demand. When supply outpaced demand, housing prices started to fall. New home prices fell 22\% from their peak of $\$ 262,600$ in March 2007 to $\$ 204,200$ in October 2010 . Falling home prices meant mortgage-holders could not sell their homes for enough to cover their outstanding loan. The Fed's rate increase couldn't have come at a worse time for these new homeowners. They couldn't afford the rising mortgage payments. The housing market bubble turned to a bust. That created the banking crisis in 2007, which spread to Wall Street in 2008. (Trichet, 2010)

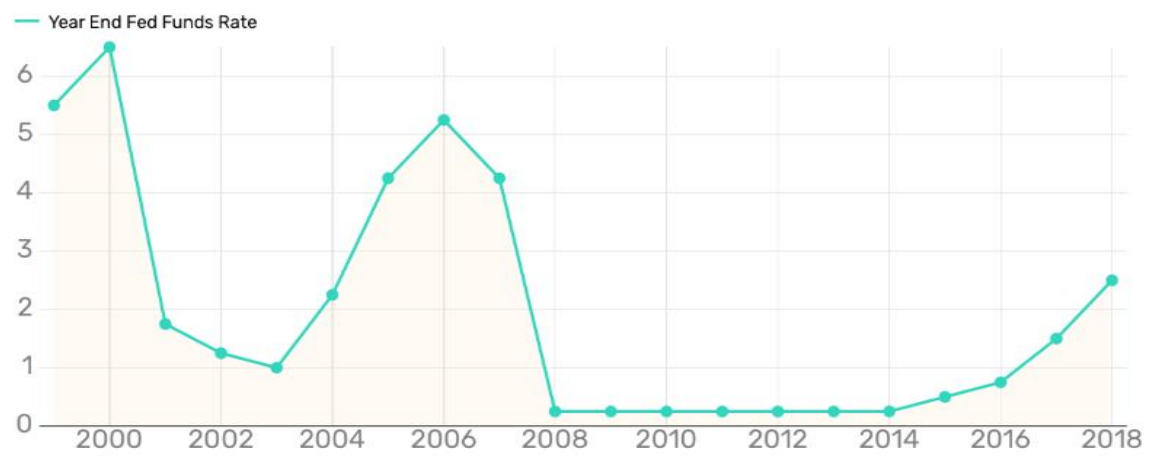

Source: Federal Reserve Report

\section{European sovereign debt crisis}

The origin and propagation of the European sovereign debt crisis can not only be attributed to the increasing fiscal deficits and rising public debt through the global crisis, but also due to some other macroeconomic and structural factors. As stated by Wolf (M., 2012), in its origin the Eurozone crisis is not a fiscal crisis, although fiscal deficits and massive debt stocks caused the sovereign debt crisis in the Eurozone. Prior to the outbreak of the global financial crisis, the debt stocks of the crisis countries were actually quite low, with the exception of Greece and Italy. Liquidity provisions and the nationalization of private banks during the period 2007-2009 resulted in an increasing debt burden in these countries. There are some other preexisting conditions that lead to the outbreak of European sovereign debt crisis. 
First, as affirmed by many economists, the Economic and Monetary Union (EMU) is a monetary union without a fiscal union. Nonetheless, this design, permitting the free riding of fiscal policies within a framework of common monetary policy, led to differences in inflation rates within the Eurozone member countries. Even before the euro (the single currency adopted by 17 of the European Union member states), individual countries had unique monetary policies.

The Northern countries generally sought low inflation, while the Southern countries, in contrast, at times used inflation to pay off debt and/or to devalue the external cost of their exports to jumpstart the economy after sluggish periods. In the publication from Harvard University "The European Financial Crisis, Analysis and a Novel Intervention", it is clearly stated that uniting the region under a common monetary policy under the ECB and focusing on keeping inflation low rather than unifying the nations under a common economic and fiscal policy fueled unstable trade balances.

In an effort to spur economic growth, low interest rates set by the ECB were used to finance debt to pay for vacations, homes, cars, and other "stimulus" purchases. This debt was largely an investment vehicle for wealthy countries in the north, with a large amount of spending being done by the smaller economies in the south. Inflation differences in turn led to a decrease in the trade competitiveness of high-inflation countries, i.e., Greece, Spain. As the option of improving the competitiveness of the economy through exchange rate depreciation was not available, because of the common currency, trade deficits rose steadily in the Southern peripheral countries. (Ari, 2014)

Moreover, the continuing structural differences between member countries impacted on the effectiveness of the common monetary policy implemented by the European Central Bank (ECB), which, over time, created macroeconomic imbalances within the Union. The main structural differences between member states were reflected in aggregate productivity and price and wage competitiveness, which in turn directly affected external balances (Darvas, 2020).

Furthermore, with the transition to monetary union, capital inflows increased towards peripheral countries. Easy access to low-interest rates led to a systemic focus on short-term boosts to GDP through spending, rather than long-term investments that would materially improve economic competitiveness, causing external deficits and an increase in private debt stock. This occurred in many European countries but has had the most disastrous effects on those that entered the crisis with less competitive economies to begin with. In the postcolonial globalized economy, Northern European economies are generally based in specialized manufacturing, finance, product design, and other capital-based and knowledge-based activities, which make them less vulnerable to economic downturns. Southern European economies, on the other hand, are generally based more on agriculture, low-skilled manufacturing, and tourism, a group of industries less capable of withstanding an economic crisis.

One may also affirm that while the Maastricht criteria and the Stability and Growth Pact (SGP) had put in place some strict fiscal rules to be respected. First, the Stability and Growth Pact set limits on the size of annual budget deficits at 3 percent of GDP and the stock of public debt of 60 percent of GDP. Second, the rules included a "no bailout" clause, with the implication that a sovereign default would occur if a national government failed to meet its debt obligations. However, these rules were violated several times, even by France and 
Germany. Debt had become so widespread that by 2011, total debt as a percentage of annual economic output had risen above $300 \%$ for France, Italy, and Spain and above 250\% for Greece. Even in fiscally conservative Germany, total debt as a percentage of annual economic output was approximately 240\%. (Esposito, 2020).

Most economist agree that the euro created a common market with a single currency without exchange rate fluctuations, creating wealth and prosperity for all country members and strengthened the role of Europe as an economic power until the crisis of subprime "borrowers being approved for loans they could not afford", which upsets in international finance since 2008, starting as a debt crisis in Greece in 2010 and as the crisis of public debt in Ireland, have firstly led to a financial crisis and then to sovereign debt crisis in the Euro-zone and the whole European Union. (Akala, 2020).

\section{COVID-19: Risks of adverse macro-financial}

The European and world economies are currently experiencing an extraordinary and severe shock, as public health measures to contain the spread of the coronavirus have halted many economic activities across the globe. In the first quarter of this year, according to preliminary flash estimates, the euro area economy declined by 3.8 percent quarter on quarter: this marks the first quarterly reversal in growth in seven years. Assessing the most likely future path for the economy is even more difficult than usual on account of the exceptional nature of the shock, which has few precedents in modern economic history. The scale and duration of the pandemic macroeconomic shock depends on how long the lockdown measures remain in place, their impact across sectors and the speed at which economic activity normalizes.

The contraction will be much more pronounced in the second quarter, since lockdown measures were in full force by April across the euro area and in many other countries. There has been a profound deterioration in labor market conditions, with a sudden and extreme decline in total hours worked, which is reflected in rising unemployment and lower labor market participation, together with extensive employment subsidy schemes in many countries in order to maintain worker-firm relationships where feasible. Furthermore, the sharp falls in consumer and business sentiment indicators in April are leading indicators of protracted adverse demand in the coming months. In addition to the negative outlook for aggregate demand, macroeconomic prospects also turn on the extent of the short-term and long-term damage to the productive capacity of the euro area economy.

A deep recession is envisaged, amounting to a contraction in real GDP of 5 percent this year. In the severe scenario, real GDP would fall by 12 percent in 2020 . At the same time, these scenarios foresee some initial rebound in economic activity in the second half of 2020 as the containment measures are gradually lifted, even if the speed and scale of the recovery over the medium term are highly uncertain. For instance, in the severe scenario developed by ECB staff, real GDP remains below the level observed at the end of 2019 throughout 2022. The current environment is also marked by substantial uncertainty concerning the outlook for inflation. Oil prices, which plunged following the COVID-19 outbreak, have strongly pushed down headline inflation. The reaction of underlying inflation to the downturn is projected to remain relatively muted in the short term. However, in the coming months, downward price pressures will be generated by weaker economic activity and lower aggregate demand. The overall net impact on medium-term inflation dynamics will depend on the balance between 
rising slack and lower aggregate demand on the one side and the possible long-term adverse impact of the virus shock on aggregate supply capacity on the other side. (Lane, 2020)

\section{Methodology}

The procedure and technique that I have used to identify, select, process, and analyze information of this topic is comparison. This will give any reader the opportunity to easily evaluate the study's overall validity, reliability and better understand how the ECB policies for three different crises are intersected. The study is primarily conceived as a theoretical approach, supported by the analysis of relevant statistical indicators on public finance. As statistical data sources I used databases and reports of ECB, Eurostat, and national central banks, as well as some published studies relevant for this research.

As I had made a kind of summary of the previous crises (last three) of their causes I will describe now the responses that ECB had for each of them and comparing them. This paper is focused mainly on the conventional monetary policy of ECB like interest rates, reserve requirements, etc. that seem to have changed during the crises. In addition, this research aims to explain some short and medium-term nonconventional monetary policy and quasi-fiscal policy like SSM that were taken by the ECB.

\section{The 2008-2009 financial crisis}

While trying to maintain price stability the ECB between October 2008 and May 2009 cut its main refinancing rate by 325 basis points, down to 1\%. In August 2007, the ECB took swift and decisive action to provide liquidity in the interbank money market to alleviate the stresses and ensure, to the maximum extent possible, that liquidity problems would not turn into solvency problems, and that systemic risk would be effectively contained. (Tropeano, 2020).

ECB also aimed to enhance credit support. It adopted a number of credit enhancement measures to mitigate the impact of collapsing wholesale and interbank markets. Starting in October 2008, the main refinancing operations (MROs) and long term refinancing operations (LTROs) were granted on a full allotment and fixed rate basis, so that all demand for liquidity would be satisfied at a stable cost as long as adequate collateral was available.

Banks did not trust each other any longer, since nobody was sure just how risky it really was to lend to another bank. In terms of economic theory, one could say that information asymmetries had become too large, with the result of a market breakdown. And economic theory also tells us that a market breakdown is justification for public sector intervention. (Grant, W., \& Wilson, G., 2012).

One other respond for this crises was applying fixed-rate full allotment' procedure in all open market operations. This gave banks as much central bank liquidity as they want at key policy interest rate, against an expanded list of eligible collateral.

One other response was the extension of maturity range from six to twelve months. And ECB represent the for the first time the "Covered Bond Purchase Programme) in order to revive a market normally representing a primary source of funding for European banks, which had dried up in terms both of liquidity and issuance; under the programme it purchased some €60 billion of securities. Collateral requirements were repeatedly eased by lowering the minimum acceptable rating and extending the list of eligible paper. The balance of the ECB shot-up to 
over $€ 2$ trillion. Also ECB launched the Securities Markets Program, which allowed the bank to buy not only private securities but also public bonds. (Albulescu, C., \& Goyeau, D., 2013)

\section{European sovereign debt crisis}

The responsibility to put an end to the sovereign debt crisis mainly goes to the national governments of the over indebted countries, forced to adopt harsh fiscal austerity policies, to cut budget deficits and reduce their public debt to sustainable levels. As we saw if the previous description many nations broke the rule of debt rate, like France, Spain, Italy, Greece and even the Germany. However, given the high risk of contagion to the financial and banking sector and the threats to financial and macroeconomic stability, these measures had to be completed and coordinated with similar monetary policy measures adopted by ECB. In the pre-crisis era, the ECB focused on the pursuit of price stability. During this crisis, the ECB became a key player by assuming the role of crisis manager (as a lender of last resort) and financial supervisor (through is designation as the Single Supervisory Mechanism).

A lender of last resort (LOLR) ensures the stability of the financial system by providing liquidity to a single financial institution or the financial system as a whole during times of crisis. During the crisis, the ECB eased liquidity not only through its standard monetary policy but also its nonconventional monetary policy and its provision of Emergency Liquidity Assistance (Chang, 2016).

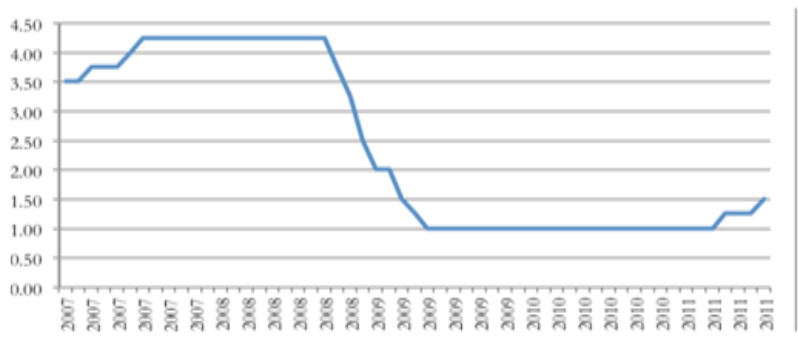

The conventional ones consisted in decreasing the key policy interest rate from 1\% in April 2010 unchanged since May 2009 to the historically low rate of $0.75 \%$ in July 2012 and reducing the minimum reserve requirements from $2 \%$ to $1 \%$, in December 2011.

Source: Eurostat, May,2020

Also the nonconventional monetary policy took place for the recovery of this crises like SMP, LTRO and OMT.

In May 2010 the ECB launched the Securities Market Program (SMP) in which it purchased the sovereign debt of peripheral economies like Greece, Ireland, Spain, Portugal and Italy on secondary markets. The ECB justified this this as necessary to "restore an appropriate monetary policy transmission mechanism, and thus the effective conduct of monetary policy oriented towards price stability in the medium term" (ECB 2010). It is important to highlight that the ECB was not purchasing sovereign bonds of all euro area members, it was purchasing those that experiencing trouble refinancing on financial markets due to their high public debt levels. This entails a certain amount of risk for the ECB in that it was purchasing the sovereign debt of countries with a questionable ability to service their debt. Between May 2010 and October 2010, about 65 billion euro of bonds were bought by the ECB; a further 125 billion 
euro were committed during the market turmoil between August 2011 and November 2011 such that the cumulative bond holdings grew to over 200 billion euros which account for 2 percent of euro area GDP. (Lane, 2020)

In addition to SMP, the ECB launched several series of long-term refinancing operations (LTROs) in 2010 in which it allowed banks to borrow money at the main refinancing rate.

In July 2012 ECB President Mario's Draghi's famous “whatever it takes speech" vowed that the ECB would defend the euro. This was operationalized with the Outright Monetary Transactions (OMT). The OMT immediately relieved market pressure, and many believe that the ECB "made the right decision to become the lender of last resort". Finally, the OMT cemented Mario Draghi's reputation as the man who rescued the euro (Chang, 2020).

The European Commission chose the ECB to conduct banking supervision within a single supervisory mechanism (SSM). The ECB received the responsibility of monitoring missions for all the participating member states' credit institutions, regardless of their business model and their size. It will ensure the implementation of standards for the degree of leverage, of liquidity, of own funds and it may, in coordination with the national authorities, impose the constitution of capital buffer or the introduction of corrective measures as deemed necessary.

\section{COVID-19 crise}

\section{Helping the economy absorb the shock of the current crisis}

The €750 billion Pandemic Emergency Purchase Programme (PEPP) aims to lower borrowing costs and increase lending in the euro area. This in turn should help citizens, firms and governments get access to funds they may need to weather the crisis. This programme complements the Asset purchase programme, which will be more detailed in October 2020.

\section{Keeping borrowing affordable}

ECB has kept their interest rates at historically low levels so borrowing costs remain low. ECB rates impact how much it costs to take out a loan. Low rates make it easier for people and companies to borrow funds, and should support spending and investment. ECB hos not defined yet an interest rate for this crises.

\section{Supporting access to credit for firms and households}

ECB has increased the amount of money that banks can borrow and made it easier for them to borrow specifically to make loans to those hardest-hit by the spread of the virus, including small and medium-sized firms. Easer methods to determine the asset values.

\section{Ensuring short-term concerns do not prevent lending}

In times of great uncertainty, banks may find it harder to secure funds for short-term needs. ECB aims to help smooth over any temporary funding issues for solvent banks by offering immediate borrowing options at favorable rates. This support helps banks continue granting loans to citizens and firms in need.

\section{Increasing banks' lending capacity}

ECB is being temporarily less strict about the amount of funds, or "capital", that banks are required to hold as a buffer for difficult times. ECB is also giving banks more flexibility on supervisory timelines, deadlines and procedures. All of these measures help euro area banks 
focus on playing their vital role as lenders during this extraordinary period. Banks are expected to use any freed-up funds to absorb losses and support the economy, and not to pay out dividends.

\section{Preserving financial stability through international cooperation}

Central banks around the world hold reserves of currencies that are not their own. This is because their domestic banks also do business in these currencies, and thus sometimes require foreign-currency loans in the course of daily business. In times of great uncertainty, customers' demand for foreign currency assets can increase. If banks do not have enough foreign currency reserves on hand to meet increased demand, markets can become unstable. So central banks have established so-called currency swap lines. These swap lines let central banks of one country exchange their national currency reserves for those of the central bank of another country - thus ensuring that central banks can meet increased demand. ECB has recently reactivated swap lines and enhanced existing swap lines with central banks across the globe in response to the current difficult situation. (ECB, 2020).

\section{Comparison}

The ECB role in the EU gradually started to change firstly when the 2008-2009 financial crisis and sovereign debt crisis happened. The EU understood that it was necessary to give the ECB more competences so that it could effectively put an end to the crises. ECB actions were guided by two overarching objectives. First, to restore the orderly functioning of euro area financial markets. And, second, to ensure that accommodative monetary policy continued to be transmitted to all parts of the single currency area, thereby supporting firms and households in shouldering the substantial economic and social costs that this crisis would imply. Due to the experience with unconventional policy measures was shared widely in the global central banking community, the global monetary policy response was much more synchronized during the debt euro zone crises.. During the 2008-2009 crisis, the European debt crisis and Covid-19 crises, the ECB has had an active involvement in solving these crises.

When comparing the policies that ECB took during the financial crisis, the Eurozone debt crisis and the ongoing Covid-19 pandemic crisis, we clearly see that there are some equivalent measures despite the different nature of these crises.

Firstly, the ECB tried to maintain price stability over the short and medium term during first two crises through low interest rates. Whereas at the Covid crises it is still not very clear on the rate interest. Even ECB will lower them, or at which rate will lower them. From one side the crises have demonstrated the importance of having an independent central bank credibly committed to price stability. But last crises show the need also for time action so acting in a more rapid way and also being more solidarized with the countries which were more damaged by crises.

In both the financial crisis of 2008-2009 and Eurozone debt crisis, the ECB focused on longterm refinancing operations (LTROs) which allowed banks to borrow money at the main refinancing rate. Whereas at the Covid-19 crises there was a lack of such perspective.

On financial crisis of 2008-09 and the pandemic crisis, ECB focused on enhancing credit support by increasing banks' lending capacity, encouraging them to maintain and expand their lending to clients, to ease funding conditions for banks and enterprises. Just like in 2008-2009 
the ECB is giving banks more flexibility on supervisory timelines, deadlines and procedures during the pandemic.

On all three crises, ECB launched securities and bonds programs. During the financial crisis, ECB launched Covered Bond Purchase Programme (CBPP1) in order to revive the market which had dried up in terms of liquidity and issuance. Also, it launched Securities Market Programme, which allowed the bank to buy not only private securities but also public bonds.

Also ECB purchased sovereign bonds, but we should mention that in purchased in countries experiencing trouble refinancing on financial markets due to their high public debt levels. During the ongoing pandemic crisis, ECB launched the Pandemic Emergency Purchase Programme (PEPP). ECB buys several different kinds of assets in this programme. For example, when the ECB buys bonds directly from banks, the ECB makes more funds available that they can lend to households or businesses.

\section{Conclusion}

All in all, we can say the responses of ECB for three crises were not the same even the main role of ECB remains the price stability during all three crises. On the other hand also as the profile of the crises is not the same we cannot expect the ECB to have the same responses, but it can be seen from the paper that the responses are equivalent in respective to crises profiles.

Also it should be understood that from crises to crises the competences of ECB gets' more and more, and of course here it is needed a future and more detailed study in order to analyze the advantages or disadvantages of this situation.

Again it is important to underline as the "time dimensions" is very important for the quasi fiscal policies it is clearly seen that there was kind of time delay of ECB responses for the Covid19 crises.

In the Covid-19 crises it is still not very clear on the rate interest. Even ECB will lower them, or at which rate will lower them.

Giving the bizarre circumstances, the ECB sometimes had to abandon its usual monetary policy and take "whatever it takes approach" in the short term and medium term so that it could cope with the crises. And this approach goes hand to hand with the solidarization approach of EU, in its own existence.

Since the covid-19 it is an ongoing issue, we cannot say for sure how effective the ECB policies will for the long run but we are clear enough for the short and medium run responses. Despite a general price recovery in late April, markets remain wary of the longer-term prospects in the banking sector. However ECB continues to act as a lender of last resort by providing liquidity in the market while dealing with the covid-19 crisis.

\section{References}

[1] Akala, I. (. (2020). The Euro-zone Financial Crisis: Causes, Consequences and Policy Responses.

[2] Albulescu, C., \& Goyeau, D. (2013). Financial instability and ECB monetary policy.

[3] Ari, A. (2014). The European Debt Crisis: Causes, Consequences, Measures and Remedies. .

[4] Chang, M. (2020). The ECB in the Sovereign Debt Crisis. . 
[5] Christine Lagarde, P. o. (12 March 2020). PRESS CONFERENCE.

[6] Darvas, Z. (.-e.-c.-t.-r.-b.-f.-s. (2020). The euro crisis: ten roots, but fewer solutions.

[7] Demertzis, M., Tagliapietra, S., Sapir, A., \& Wolf, G. (2020, 3 13). An effective economic response to the coronavirus in Europe. Retrieved from Brugel: https://www.bruegel.org/wp-content/uploads/2020/03/PC-06-2020-130320.pdf

[8] ECB. (2020). Our response to the coronavirus pandemic. .

[9] Esposito, M. \&. (2020). The European Financial Crisis. .

[10] European Central Bank. (2020). Our response to the coronavirus pandemic. Retrieved from European Central Bank: https://www.ecb.europa.eu/home/search/coronavirus/html/index.en.html

[11] Fernando, W. M. (2020). The economic impact of COVID-19. London: CEPR Press.

[12] Grant, W., \& Wilson, G. (2012). The Consequences of the Global Financial Crisis.

[13] Iñaki, A., Ingo , F., Bryan , H., \& Nikola , T. (2020, 5 7). Effects of Covid-19 on the banking. Bank for International Settlements, p. 6.

[14] Lane, P. R. $(2020,51)$. The monetary policy response to the pandemic emergency. Retrieved from European Central Bank: https://www.ecb.europa.eu/press/blog/date/2020/html/ecb.blog200501 a2d8f 514a0.en.html

[15] M., W. (2012). "Why the Eurozone Crisis is not Over", Speech at the Peterson Institute for International Economics.

[16] Trichet, J. (2010). Lessons for financial stability and monetary policies. Retrieved 31 May 2020.

[17] Tropeano, D. (2020). The monetary policy response to the financial crisis in the Euro area and in the United States: a comparison.

[18] Walker, A. $(2020,56)$. Coronavirus: EU facing 'deep and uneven recession'. Retrieved from BBC Business: https://www.bbc.com/news/business-52557191 